\title{
Formulasi Transdermal Patch Ekstrak Etanol Biji Pepaya (Carica Papaya L.) Dengan Basis Hydroxypropil Metilcellulose (HPMC)
}

\author{
Viqi Kurnia Wardani ${ }^{*}$, Dwi Saryanti ${ }^{1}$ \\ 1. Departemen Teknologi Farmasi Program Studi D3 Farmasi Sekolah Tinggi Ilmu \\ Kesehatan Nasional Surakarta
}

Korespondensi : viqikurnia2016@gmail.com

\begin{abstract}
ABSTRAK
Pendahuluan : Biji pepaya (Carica papaya L.) memiliki kandungan metabolit sekunder seperti flavonoid yang bersifat sebagai antioksidan. Ekstrak etanol biji pepaya diformulasikan menjadi transdermal patch untuk menghindari first pass effect dan menjaga bioavailabilitas obat dalam plasma. Selain itu flavonoid memiliki kelarutan yang rendah sehingga dibuat menjadi transdermal patch untuk meningkatkan bioavailabilitasnya.Penelitian ini bertujuan untuk mengetahui konsentrasi HPMC yang dapat menghasilkan stabilitas fisik yang baik serta mengetahui adanya pengaruh perbedaan konsentrasi HPMC pada stabilitas fisik transdermal patch.

Metode : Biji pepaya diekstraksi menggunakan metode maserasi dengan etanol 95\%. Ekstrak biji pepaya dibuat sediaan transdermal patch menggunakan polimer HPMC dengan konsentrasi $1 \%, 2 \%, 3 \%$. Sediaan patch yang diperoleh dilakukan pengujian meliputi organoleptis, keseragaman bobot, susut pengeringan, ketebalan, daya serap kelembaban, ketahanan lipat, dan $\mathrm{pH}$.

Hasil : Hasil uji sifat fisik formula sediaan transdermal patch mempunyai bobot patch berkisar $0,27-0,49 \mathrm{~g}$, tebal patch $0,01-0,03 \mathrm{~mm}$, susut pengeringan $0 \%$ dan daya serap kelembaban 12,01 - 21\%. Berdasarkan penelitian formulasi ekstrak biji pepaya pada sediaan transdermal patch menunjukkan bahwa penambahan HPMC memiliki pengaruh meningkatkan bobot, ketebalan, ketahanan lipat, dan daya serap kelembaban.

Kesimpulan: Transdermal patch dengan konsentrasi HPMC 1\% memiliki stabilitas fisik yang paling baik. Perbedaan konsentrasi HPMC dapat berpengaruh terhadap stabilitas fisik sediaan transdermal patch, semakin tinggi konsentrasi HPMC akan meningkatkan bobot, ketebalan, daya serap kelembaban, dan ketahanan lipat.
\end{abstract}

Kata kunci: Biji Pepaya; HPMC; Transdermal Patch.

\begin{abstract}
Introducion : Papaya seeds contain secondary metabolites such as flavonoids, that are antioxidants. Ethanolic extract of Papaya seed (Carica papaya L.) was formulated into transdermal patch to avoid the fist pass effect and maintain the bioavailability of drugs in plasma. Flavonoids have low solubility so that transdermal patches are made to increase their bioavailability. This research aims to determine the concentration of HPMC which can produce a good physical stability and the effect of HPMC concentration on the physical stability of the transdermal patch.

Methods : Papaya seeds were extracted using maceration method with $95 \%$ ethanol. It is made into transdermal patch with 1\%, 2\%, 3\% concentration of polymer HPMC. There are some testing include organoleptic, uniformity of weight, drying shrinkage, thickness, moisture uptake, folding endurance and $\mathrm{pH}$.

Results : The physical test results of the transdermal patch preparation formula have patch weights ranging from $0.27-0.49 \mathrm{~g}$, patch thickness $0.01-0.03 \mathrm{~mm}$, drying shrinkage $0 \%$ and moisture absorption $12.01-21 \%$. Based on research on papaya seed extract formulation
\end{abstract}


in transdermal patch preparations, the addition of HPMC has the effect of increasing weight, thickness, folding resistance, and moisture absorption.

Conclusion: Transdermal patches with 1\% HPMC concentration have the best physical stability. Differences in HPMC concentration may affect the physical stability of transdermal patch supplies, the higher the HPMC concentration will increase weight, thickness, moisture absorption, and folding resistance.

Keyword: Papaya seeds; HPMC; Transdermal Patch.

\section{PENDAHULUAN}

Pengobatan alternatif dapat dilakukan dalam meningkatkan penggunaan tumbuhan berkhasiat obat dikalangan masyarakat ${ }^{1,2}$. Salah satu kekayaan alam Indonesia adalah tanaman pepaya. Hampir semua bagian tanaman pepaya memiliki memiliki khasiat untuk tubuh, salah satunya pada biji pepaya yang biasa dibuang sebagai limbah ternyata juga mempunyai khasiat yang berguna bagi tubuh. Biji pepaya memiliki kandungan senyawa fenolik dan flavonoid yang dapat berkontribusi dalam aktivitas antioksidan. Pemberian ekstrak etanol biji pepaya memiliki aktivitas sebagai hepatoprotektor karena adanya kandungan antioksidan pada biji pepaya. Ekstrak etanol biji pepaya dapat melindungi hati pada tikus putih yang diinduksi dengan parasetamol dengan dosis efektif $500 \mathrm{mg} / \mathrm{kg}$ BB yang dilihat dari parameter SGOT-SGPT pada serum darah tikus $^{3}$.

Senyawa yang diduga berperan aktif sebagai antioksidan adalah flavonioid dan fenolik. Flavonoid memiliki kelarutan yang rendah dalam air disertai waktu pengisian yang pendek dalam usus halus, sehingga dibuatlah transdermal patch untuk meningkatkan bioavailabilitasnya ${ }^{4}$. Rute penghantaran obat secara transdermal merupakan alternatif untuk beberapa obat. Transdermal patch merupakan bentuk sediaan yang menghantarkan obat melewatikulit untuk menghasilkan efek sistemik dengan kecepatan yang dapat dikontrol. Keuntungannya antara lain penggunaan yang mudah, dapat mengurangi frekuensi pemberian obat, menjaga bioavailabilitas, menghindari first pass effect dapat dimetabolisme secara cepat sehingga obat yang mencapai sirkulasi sistemik menjadi jauh berkurang 5 .
Pada pembuatan transdermal patch, polimer merupakan bahan yang paling penting dalam pembuatan matriks patch sebab polimer yang digunakan akan menentukan kecepatan pelepasan obat yang nantinya akan mempengaruhi keberhasilan terapi. Penggunaan polimer HPMC merupakan salah satu polimer yang paling banyak digunakan dalam penghantaran obat secara topikal karena sifatnya yang tidak beracun, tidak mengiritasi dan kompatibel dengan berbagai macam bahan obat dan eksipien ${ }^{6}$.

Tujuan dari penelitian ini adalah untuk mengetahui konsentrasi HPMC yang dapat menghasilkan stabilitas fisik yang baik pada sediaan transdermal patch serta untuk mengetahui pengaruh adanya perbedaan konsentrasi HPMC.

\section{METODE PENELITIAN}

\section{Alat dan Bahan}

Alat-alat yang digunakan dalam penelitian ini adalah alat-alat Gelas (Pyrex), Desikator, Oven (Memmert), Timbangan Digital, Cawan Petri, Rotary Evaporator (Buchi R 100 II), Waterbath, Blender (Philips), Mortir dan Stamper, Ayakan No. 20 Mesh, Toples kaca, Jangka Sorong.

Bahan-bahan yang digunakan dalam penelitian ini adalah biji pepaya Calina (Carica papaya L.) (diperoleh dari daerah Gemolong, Sragen), HPMC (Brataco), Propilenglikol (Brataco), metil paraben (Brataco), etano195\% (Brataco), aquadest, Serbuk $\mathrm{Mg}, \mathrm{HCl} P$.

\section{Pengolahan Simplisia}

Biji pepaya disortasi basah, setelah itu dilakukan pencucian menggunakan air mengalir yang bersih 
untuk menghilangkan kotoran yang menempel. Proses pengeringan dilakukan dengan menggunakan oven yang bertujuan untuk mengurangi kadar air dan mencegah pertumbuhan mikroorganisme, setelah dikeringkan dihaluskan menggunakan blender sehingga didapatkan serbuk simplisia kemudian diayak.

\section{Pembuatan Ekstrak}

Serbuk biji pepaya dimaserasi menggunakan pelarut etanol $95 \%$ selama 5 hari dan diremaserasi selama 2 hari sambil sesekali diaduk, filtrat yang diperoleh dikumpulkan kemudian diuapkan dengan menggunakan evaporator lalu dipekatkan menggunakan waterbath sampai didapat ekstrak kental. Rendemen ekstrak yang diperoleh dihitung dengan presentase bobot $\mathrm{b} / \mathrm{b}$.

\section{Identifikasi Senyawa Flavonoid}

Larutan ekstrak direaksikan dengan serbuk $\mathrm{Mg}$ dan asam klorida pekat. Hasil positif jika terbentuk warna jingga ${ }^{7}$.

\section{Rancangan Formula}

Formulasi patch yang mengandung ekstrak etanol biji pepaya dirancang dalam 3 formula dengan menggunakan basis HPMC sebagaimana yang ditunjukkan pada Tabel1.

Tabel 1. Formula pembuatan Transdermal Patch Ekstrak Etanol Biji Pepaya (Carica papaya L)

\begin{tabular}{lllll}
\hline Bahan & F1(\%) & F2(\%) & F3(\%) & Fungsi \\
\hline $\begin{array}{l}\text { Ekstrak } \\
\text { biji pepaya }\end{array}$ & 6 & 6 & 6 & Zat aktif \\
HPMC & 1 & 2 & 3 & Basis \\
$\begin{array}{l}\text { Metil } \\
\text { Paraben }\end{array}$ & 0,3 & 0,3 & 0,3 & Pengawet \\
$\begin{array}{l}\text { Propilengli } \\
\text { kol }\end{array}$ & 10 & 10 & 10 & $\begin{array}{l}\text { Penetration } \\
\text { enhancer }\end{array}$ \\
$\begin{array}{l}\text { Etanol95\% } \\
\text { Corr. }\end{array}$ & 40 & 40 & 40 & Pelarut \\
Odoris & Qs & Qs & Qs & Pengaroma \\
Aquadest & $\begin{array}{l}\text { Ad } \\
100\end{array}$ & $\begin{array}{l}\text { Ad } \\
100\end{array}$ & $\begin{array}{l}\text { Ad } \\
100\end{array}$ & Pelarut \\
\hline
\end{tabular}

\section{Pembuatan Sediaan}

Ekstrak etanol biji pepaya dilarutkan dengan $5 \mathrm{ml}$ aquadest dan $10 \mathrm{ml}$ etanol (campuran 1). Kembangkan HPMC dengan aquadest (campuran 2). Metil Parabendilarutkan dalam propilenglikol (campouran 3). Campuran 1 ditambahkan pada campuran 2, diaduk homogen, kemudian tambahkan campuran 3 diaduk homogen. Etanol ditambahkan ke ke dalam campuran diaduk homogen. Ditambahkan aquadest hingga $100 \mathrm{~g}$. Selanjutnya didiamkan \pm 20 jam, kemudian tuang ke cawan petri berdiameter $5 \mathrm{~cm}$ sebanyak $\pm 3 \mathrm{~g}$. Dioven pada suhu $50^{\circ} \mathrm{C}$, setelah kering dimasukkan ke desikator selama kurang lebih 20 jam. Patch dilepas dari cetakan dan disimpan dalam wadah tertutup.

\section{Evaluasi Sediaan}

\section{a. Uji Organoleptis}

Dilakukan dengan mengamati perubahanperubahan yang meliputi bentuk, warna, rasa, dan bau pada sediaan.

b. Uji Keseragaman bobot

Bobot patch ditimbang dengan menggunakan neraca analitik, timbang masing-masing 3 patch kemudian tentukan berat rata-ratanya, standar deviasinya dan $\%$ CV. ${ }^{8}$ Bobot patch dikatakan seragam apabila nilai $\mathrm{CV} \leq 5 \%$.

\section{c. Uji Susut pengeringan}

Patch ditimbang dan disimpan pada desikator selama 24 jam yang terdapat silica. Setelah 24 jam patch ditimbang ulang dan ditentukan presentase susut pengeringan ${ }^{8}$. Tidak ada nilai mutlak berapa jumlah susut pengeringan yang disyaratkan?

\section{d. Uji Ketebalan}

Pengujian ketebalan patch pada tiap formula adalah dengan mengukur ketebalan satu persatu 3 patch. Pengukuran tebal patch menggunakan alat jangka sorong dan dilakukan pada 3 titik yang berbeda ${ }^{10}$. Ketebalan memiliki peran dalam sifat fisik patch, patch yang tipis akan lebih mudah diterima dalam pemakaiannya ${ }^{11}$. 


\section{e. Uji Daya serap kelembaban}

Patch yang telah disimpan pada suhu ruang dalam desikator selama 24 jam ditimbang terlebih dahulu, selanjutnya dipaparkan pada suhu $40^{\circ} \mathrm{C}$ selama 24 jam dan ditimbang kembali ${ }^{11}$. Berdasarkan penelitian sebelumnya disebutkan bahwa nilai persen daya serap lembab berkisar 3,52$9,79 \%^{9}$.

\section{f. Uji Ketahanan lipat}

Pengujian ketahanan terhadap pelipatan dilakukan dengan patch berkali-kali pada posisi yang sama. Jumlah pelipatan tersebut yang dianggap sebagai nilai ketahanan terhadap pelipatan. Peningkatan ketahanan lipat dari suatu patch mengindikasikan bahwa patch memiliki konsistensi film yang bagus, sehingga tidak mudah patah atau robek saat penyimpanan ${ }^{12}$.

\section{g. $\quad \mathbf{j i} \mathbf{~ p H}$}

Patch ditempatkan kedalam cawan porselen yang berisi $5 \mathrm{ml}$ aquadest $(\mathrm{pH} 6,5)$ dan biarkan mengembang selama 2 jam pada suhu ruangan dan $\mathrm{pH}$ ditentukan dengan meletakkan kertas $\mathrm{pH}$ pada permukaan patch. Dihitung nilai rata-ratanya kemudian dihitung standar deviasinya ${ }^{13}$.

\section{Analisis Data}

Analisa data yang diperoleh meliputi uji organoleptis, uji keseragaman bobot, uji susut pengeringan, uji ketebalan, uji daya serap, uji ketahanan lipat, uji pH yang terlebih dahulu dibuat grafik kecuali uji organoleptis kemudian dianalisis satu arah (one way) ANOVA dengan aplikasi SPSS.

\section{HASIL}

Hasil pengujian sifat fisik sediaan transdermal patch ekstrak biji pepaya dapat dilihat pada tabel 2. Hasil uji sifat fisik transdermal patch ekstrak biji papaya didapatkan perbedaan sifat fisik pada keseragaman bobot, ketebalan, daya serap kelembaban, dan ketahanan lipat antara formula I, II, dan III.
Tabel 2. Hasil uji sifat fisik transdermal patch ekstrak biji pepaya

\begin{tabular}{llll}
\hline Sifat fisik & $\begin{array}{l}\text { Formula } \\
\text { I }\end{array}$ & $\begin{array}{l}\text { Formula } \\
\text { II }\end{array}$ & $\begin{array}{l}\text { Formula } \\
\text { III }\end{array}$ \\
\hline Organoleptis & $\begin{array}{l}\text { Warna } \\
\text { coklat, } \\
\text { halus, } \\
\text { aroma } \\
\text { melati }\end{array}$ & $\begin{array}{l}\text { Warna } \\
\text { coklat, } \\
\text { halus, } \\
\text { aroma } \\
\text { melati }\end{array}$ & $\begin{array}{l}\text { Warna } \\
\text { coklat, } \\
\text { halus, } \\
\text { aroma } \\
\text { melati } \\
0,67\end{array}$ \\
$\begin{array}{l}\text { Keseragaman } \\
\text { bobot (\%) }\end{array}$ & 0,50 & 0,75 \\
$\begin{array}{l}\text { Susut } \\
\text { pengeringan } \\
(\%)\end{array}$ & 0 & 0 & 0 \\
$\begin{array}{l}\text { Ketebalan } \\
\text { (mm) }\end{array}$ & 0,01 & 0,02 & 0,03 \\
$\begin{array}{l}\text { Daya serap } \\
\text { kelembaban } \\
(\%)\end{array}$ & 12,01 & 13,87 & 21 \\
$\begin{array}{l}\text { Ketahanan } \\
\text { lipat } \\
\text { pH }\end{array}$ & $>200$ & $>400$ & $>600$ \\
\hline
\end{tabular}

\section{PEMBAHASAN}

Pembuatan ekstrak biji pepaya dilakukan dengan metode maserasi. Metode maserasi dipilih karena dianggap lebih mudah, lebih aman dan resiko kehilangan zat aktif lebih sedikit karena menggunakan metode ekstraksi dingin tanpa adanya pemanasan. Selain itu senyawa yang terdapat pada zat aktif tidak tahan pemanasan. Senyawa flavonoid relatif aman pada suhu $50^{\circ} \mathrm{C}$. Flavonoid merupakan senyawa fenol yang memiliki sistem aromatik yang terkonjugasi. Sistem aromatik terkonjugasi mudah rusak pada suhu tinggi ${ }^{14}$. Hasil rendemen ekstrak etanol biji pepaya yaitu sebesar $6,17 \%$ b/b.Hal ini sesuai dengan persyaratan ekstrak kental 5-30\% ${ }^{15}$. Hasil identifikasi secara kualitatif pada ekstrak etanol biji pepaya diperoleh hasil positif pada pengujian identifikasi senyawa flavonoid yang ditandai adanya perubahan warna menjadi jingga.

Formulasi transdermal patch menggunakan ekstrak biji pepaya sebagai bahan aktif, HPMC sebagai polimer atau basis, Propilenglikol sebagai penetration enhancer, Etanol dan aquadest sebagai pelarut serta corrigen melati sebagai corrigen odoris untuk menutupi bau yang kurang menyenangkan dari ekstrak etanol biji pepaya. 
Pada formulasi yang dilakukan dengan dosis ekstrak etanol biji pepaya $6 \mathrm{~g}$ dengan metode pembuatan solvent casing dengan variasi konsentrasi HPMC yaitu 1: 2: 3. Transdermal patch yang telah terbentuk dilakukan evaluasi fisik untuk melihat kestabilan fisik sediaan transdermal patch yang meliputi, uji organoleptis, uji keseragaman bobot, uji susut pengeringan, uji ketebalan, uji daya serap, uji ketahanan lipat dan uji $\mathrm{pH}$.

Pengujian organoleptis merupakan pengujian dengan menggunakan indera manusia sebagai parameter kenyamanan sediaan yang dapat diterima oleh masyarakat. Sediaan transdermal patch memiliki organoleptis, warna coklat, tekstur halus dan bau melati. HPMC sebagai polimer juga menghasilkan penampilan fisik yang tidak menghasilkan adanya aerasi dan keriput sehingga tekstur yang dihasilkan halus.

Pengujian keseragaman bobot bertujuan untuk mengetahui kesamaan dari bobot masingmasing patch yang ditujukan untuk mengevaluasi konsistensi proses pembuatan dalam menghasilkan produk yang seragam dalam hal ini menyangkut dengan dosis obat yang seragam pada setiap satuan sediaan. Keseragaman dosis sangat penting pada sediaan obat, dimana bobot patch harus seragam dan nilai $\mathrm{CV} \leq 5 \%$. Hasil pengukuran menunjukkan formula 1 memiliki rata-rata bobot $0,27 \mathrm{~g}$, formula $20,45 \mathrm{~g}$, dan formula $30,49 \mathrm{~g}$. Berdasarkan table 2 juga dapat dilihat bahwa nilai $\mathrm{CV}$ dari keseragaman bobot yang dihasilkan juga memenuhi syarat dimana nilai CV tidak boleh lebih dari 5\%.

Pengujian ketebalan pada transdermal patchbertujuan untuk mengetahui keseragaman ketebalan patch yang dihasilkan, ketebalan yang diperoleh menunjukkan adanya keseragaman larutan patch yang dituang pada cetakan. Hasil ketebalan patch berkaitan dengan keseragaman bobot semakin tinggi konsentrasi polimer HPMC dapat meningkatkan ketebalan patch. Ketebalan memiliki peran dalam sifat fisik patch, patch yang tipis akan mudah diterima dalam pemakaiannya ${ }^{12}$. Pada formula 1 ketebalan patch $0,01 \mathrm{~mm}$, formula 2 dengan ketebalan $0,02 \mathrm{~mm}$ dan untuk formula 3 mempunyai ketebalan $0,03 \mathrm{~mm}$. Hasil ketebalan yang diperoleh pada masing-masing formula sesuai dengan persyaratan ketebalan patch yaitu tidak boleh lebih dari $1 \mathrm{~mm}$, apabila patch terlalu tebal maka akan sulit melepaskan zat aktif dari patch $^{16}$.

Pengujian susut pengeringan bertujuan untuk mengetahui susut pengeringan, kandungan lembab pada patch setelah penyimpanan 1x24 jam didalam desikator. Hasil uji susut pengeringan didaptkan presentasi $0 \%$ dari formula 1 sampai formula 3. Besarnya nilai susut pengeringan dapat dipengaruhi pengaturan kandungan lembab.

Kadar air dalam sediaan patch menunjukkan patch yang benar stabil dengan nilai $\%$ yang rendah akan melindungi patch dari cemaran atau kontaminasi mikroba ${ }^{17}$.

Pengujian $\mathrm{pH}$ bertujuan untuk mengetahui keamanan sediaan. $\mathrm{pH}$ tidak boleh terlalu asam karena dapat mengiritasi kulit dan juga tidak boleh terlalu basa karena dapat menyebabkan kulit bersisik. Hasil pengujian pada uji $\mathrm{pH}$ didapatkan nilai $\mathrm{pH}$ yang berkisar

5-7 sehingga masih memenuhi $\mathrm{pH}$ yang aman untuk penggunaan topikal karena range $\mathrm{pH}$ untuk penggunaan topikal antara $4-8^{18}$.

Pengujian ketahanan lipat dilakukan dengan tujuan untuk mengetahui fleksibelitas dan elastisitas patch setelah dilipat pada sudut yang sama. Peningkatan ketahanan lipat dari suatu patch mengindikasikan bahwa patch memiliki konsistensi yang bagus sehingga tidak mudah patah atau robek pada saat penyimpanan. Jumlah ketahanan lipat yang memenuhi standar yaitu $>200$. Hasil yang didapatkan yaitu pada formula 1 $>200$ lipat, formula $2>400$ lipat dan untuk formula $3>600$ lipat. $^{12}$ Penggunaan propilenglikol selain sebagai penetration enhancer juga berperan sebagai plasticizer yang memiliki fungsi untuk meningkatkan fleksibelitas patch dan untuk mencegah film pecah atau sobek $^{19}$.

Pengujian daya serap kelembaban bertujuan untuk mengetahui tingkat penyerapan air dari transdermal patch yang dikondisikan pada suhu $40^{\circ} \mathrm{C}$ selama 24 jam. Pengaplikasian serap kelembaban patch pada kulit menunjukkan tingkat penyerapan air pada patch selama penggunaan ${ }^{1\urcorner 7}$. Ketahanan patch terhadap kelembaban yang dimana patch banyak menyerap 

(HPMC)

lembab akan mempengaruhi kualitas patch, yang dapat mempengaruhi elastisitas patch sehingga dapat mudah robek $^{20}$. Hasil pengujian uji daya serap kelembaban menunjukkan nilai serap kelembaban pada formula $112,01 \% \pm 0,4850$, formula 2 menunjukkan nilai serap kelembaban $13,87 \% \pm 1,9899$ dan formula 3 menunjukkan nilai serap kelembaban $21 \% \pm 0,8960$. Persen daya serap kelembaban dari film akan meningkat seiring dengan peningkatan polimer, plasticizer dan enhancer ${ }^{21}$.

Berdasarkan penelitian sebelumnya disebutkan bahwa nilai persen daya serap lembab yang baik berkisar 3,52-9,79\% ${ }^{9}$. Pada pengujian ini menunjukkan bahwa persen kelembaban yang cukup tinggi hal ini kemungkinan dipengaruhi oleh higroskopisitas dari ekstrak.

\section{KESIMPULAN}

Konsentrasi HPMC 1\% menghasilkan stabilitas fisik yang baik pada sediaan transdermal patch. Perbedaan konsentrasi HPMC dapat berpengaruh terhadap stabilitas fisik sediaan transdermal patch, semakin tinggi konsentrasi HPMC akan meningkatkan bobot, ketebalan, daya serap kelembaban, dan ketahanan lipat.

\section{DAFTAR PUSTAKA}

1. Anonim, 2010, Pedoman penulisan karya ilmiah universitas lampung, Universitas Lampung Press, Lampung.

2. Sukadana,I.M., dkk., 2008, Aktivitas Antibakteri Senyawa Golongan Triterpenoid Dari Biji Pepaya (Carica papaya L.). Jurusan Kimia FMIPA Universitas Udayana, Bali.

3. Nair V,Kandavilli S, Panchagnula R, 2002, Polymers in Transdermal, Pharm Thecnol.

4. Santi Widiasari, 2018, Mekanisme Inhibisi Angiotensin Converting Enzym oleh Flavonoid pada Hipertensi, Jurnal Departemen Biomedik Fakultas Kedokteran dan Ilmu Kesehatan Universitas Abdurrab, Riau.

5. Nurul, Novita, Welinda, D.A, dan Muhammad, A.M, 2016, Uji Aktivitas Biji Pepaya (Carica papaya L.) Sebagai Hepatoprotektor Pada Tikus Putih (Rattus norvegicus), Jurnal Fakultas Farmasi Universitas Mulawarman, Samarinda.

6. Syamsuni H.A., 2006, Farmasetika Dasar dan Hitungan Farmasi, EGC, Jakarta.
7. Markham, K.R., 1998,Cara Mengidentifikasi Flavonoid, ITB, Bandung.

8. Parivesh,S., Dwivedi,S., dan Dwivedi, A,2010, Design, evaluation, parameters and marketed products of transdermal patchs : a Review international journal of pharmacy research.3(2:235-249)

9. Patel , L.S., Patel, T.J., Mistry, P.C., Rana, A.K., Patel, P.K., dan Mishra, R.S., 2009. Development and Evaluation of Ethyl Cellulose-Based Transdermal Films of Furosemide for Improved In Vitro Skin Permeation. Pharm. Sci. Tech. Vol. 10(2) : 437-442.

10. Puspitasari, K.D., Nurahmanto, D. Dan Ameliana, L., (2016), Optimasi Hidroksipropil Metilselilosa dan Carbopol terhadap Moisture Content dan Laju Pelepasan Patch Ibuprofen In Vitro, e-Journal Pustaka Kesehatan, 4(2),pp.229-234.

11. Prabhakara, P., Koland, M., Vijaynaraya, K., Haaris, NM., Shankar, GA., Narayana, C.R., Satyanaraya, 2010, preparationand evaluation of transdermal patches of papaverin hydrochloride, J.Res.Pharm ., 1:259-266

12. Jaydatt K. Jadhav, Sreenivas, 2012, Formulation and invitro evaluation of Endometachin Transdermal Patches Using Polimes PVP and Etil Cellulose, Pharmaceutical Sciences, Vol.4(1):1-7

13. Amatia.N.Tiensi.,Tri, R.S., T.N. Saifullah , 2018, Formulasi Patch Bukal Minyak Atsiri Daun Sirih (Piper Betle L.) dengan Variansi Kadar CMC-Na dan karbopol sebagai Polimer Mukoadhesif, Majalah Farmasetika, 14(1).

14. Oktavia, J.D, 2011, Pengoptimuman Ekstraksi Flavonoid Daun Salam (Syzygium polyanthum) dan Analisis Sisik Jari dengan Kromatografi Lapis Tipis, Jurnal Fakultas Matematika dan Ilmu Pengetahuan Alam Institut Pertanian Bogor, Bogor.

15. Voigt R, 1995, Buku Pelajaran Teknologi Farmasi, Gadjah Mada University Press, Yogyakarta.

16. Shirsand SB, Ladhane GM, Prathap S, Prakash P, 2012,Design and Evaluation of Matrix Type of Transdermal Patches of Methotrexate, RGUHS J Pharm Sci. 2(4):5865.

17. Kumar, S.D., Sairan, R., Anandadabu, S., Karpagavali., Maheswara, A., dan Narayanan, N., 2012, Formulation and Evaluation Transdermal Patchs of Salbutamol. Res. Jour. Phar. Bio. Chem. Sci. Vol.3: 1132-1139.

18. Tranggono, Retno, I., Latifah, Fatmah, 2007, Buku Pegangan Ilmu Kosmetik, PT Gramedia Pustaka Utama, Jakarta.

19. Sahoo, Kumar Biraj., dan Amlya Kenta Mishra, 2013, Formulation and Evaluation of Transdermal Patches of Diklofenac, 
Wardani dan Saryanti, Formulasi Transdermal Patch Eksrak Eanol Biji Pepaya dengan Basis Hydroxypropil Metilcellulose (HPMC)

Departement of Pharmaceutical Science Marine Drive Road Puri, Odisha, India.

20. Nurahmanto, Dwi, 2015, Formulasi dan Evaluasi Sediaan Patch Transdermal Prometazin $\mathrm{HCl}$ Swbagai Pengobatan Morning Sickness, Jurnal Universitas Jember, Jember.
21. Ammar, H.O., 2009, Polymeric Matriks System for Prolomged Delivery of Tramadol Hydrocloride Part 1, Physichocemical Evaluation: AAPS Pharm Scitech. 